\title{
Cognitive Working Performance in Moderate Cold Thermal Environment: a systematic review
}

\author{
Tomi Zlatar \\ Research Laboratory on Prevention of Occupational and Environmental Risks \\ (PROA/LABIOMEP), Faculty of Engineering University of Porto, Porto, Portugal \\ (tomi.zlatar@gmail.com)
}

\begin{abstract}
Presence of cold thermal environment represents significant risk factors high latitudes, during winter seasons and in a large number of industrial activities, influencing the cognitive working performance. The aim of this work is to contribute with a systematic review on cognitive working performance in moderate cold thermal environment, by classifying different studies conducted in that area. By using appropriate keywords and searching electronic databases, a systematic review of English articles has been conducted. Only articles related to cognitive working performance in moderate cold thermal environment were included. Nine experimental articles were included. The number of participants varied from 6 to 22 subjects. The findings of this systematic review indicate that moderate cold environment influence the cognitive performance by decreasing working performance, reaction time, executive function and attention and it remain decreased for some time after cold exposure, even when the core and skin temperature get stabilized.
\end{abstract}

Subject Headings. Occupational health, Storage of food.

Author Keywords. Occupational safety and health, Mental performance, Cold temperature, Food industry.

\section{Introduction}

Cold thermal environment is present in high latitude environments (Mäkinen 2007), in outdoor during the winter season and indoor present in all seasons (Tochihara 2005). Indoor exposure is mostly related to working activities in the fresh food industry with temperatures from $0-10^{\circ} \mathrm{C}$ and frozen goods at temperatures below $-20^{\circ} \mathrm{C}$, while cold exposure in outdoor activities is present in occupations such as marine, army, agriculture, forestry, mining, factory work, construction work and related occupations (Mäkinen, Raatikka, et al. 2006).

The degree of exposure to cold is dependent on several factors such as occupation, gender, age, health, exercise activity, and education (Mäkinen, 2007).

Moderate cold impairs performance on tasks of low physical activity and requiring concentration and vigilance. These are for example cognitive performance and postural control. Some positive effects of moderate cold exposure on cognition may also occur, reflected as shorter response times and improved accuracy (Mäkinen 2007).

The phase of the menstrual cycle was found to be an important factor when conducting experiments on female subjects, as the level of the body temperature has high differences between the follicular and the luteal phase. Therefore, female subjects should be always in the first phase (follicular) of the menstrual cycle (Janse de Jonge 2003). 
Although some aspects of the influence of moderate cold thermal environment on cognitive working performance are known, there is still a need to increase the quantity and quality of studies which approach this topic. The aim of this work is to contribute with a systematic review on cognitive working performance in moderate cold thermal environment, by classifying different studies conducted in that area.

\section{Materials and Methods}

The academic and clinic PRISMA Statement (Preferred Reporting Items for Systematic Reviews and Meta-Analyses) was used in creating and modeling of this article (Liberati et al. 2009). References were managed using Mendeley.

\subsection{Searching strategy}

The process of creating the database of articles related to the influence of cold thermal environment on human fatigue and performance was divided into searching methods. The first searching method was the Meta Search of databases in the area of engineering, health and the multidisciplinary area. Access/login for searching databases was attempted by using the institutional IP address of University of Porto federate credentials. For searching purposes, keywords were defined: "cold human performance", "cold human effect", "cold human influence" and "cold human fatigue".

After keywords were defined, two electronic database types ("E-Journal" and "Index") were searched by title, without using quotation marks on keywords, in order to allow a different order of words in the title.

In addition to the Meta Search, databases in the engineering ("Compendex", "Inspec", "IEEE Xplore" and "ScienceDirect (eJournals)"), health ("MEDLINE (EBSCO)", "PsycArticles", "PubMed", "BioMed Central Journals", "nature.com" and "Science Magazine") and multidisciplinary area ("Current Contents", "Web of Science", "SCOPUS", "Informaworld (Taylor and Francis)", "SpringerLink", "Directory of Open Acces Journals (DOAJ)", "Emerald Fulltext", "Oxford Journals", "SAGE Journals Online", "Wiley Online Library" and "Cambridge Journals Online") were searched thoroughly. In total, 21 databases were searched thoroughly by title, using same keywords as for the Meta Search.

All articles that were connected with the topic to the chosen articles were screened, and if connected with the systematic review objective, they were downloaded. Articles that were citing the chosen articles were also screened and if relevant included in this systematic review.

\subsection{Inclusion criteria}

Articles were eligible if they met the criteria of being related with the influence of cold thermal environment on human cognitive fatigue. Articles published before 2000 were not considered in the Meta search and search through databases in engineering, health and multidisciplinary area. Only articles published in English language and that were free for downloading by using the University of Porto federate credentials were included.

\section{Results}

In the identification process, the searching process resulted with 198 articles, of which 181 were published after the year 2000, all in English language. Repeated articles were excluded which resulted with 138 articles to consider. By screening article titles additional 4 articles were excluded which resulted in a total of 134 articles to consider. By screening article abstracts additional 18 articles were excluded which resulted with a total of 116 articles to 
consider. Additional 27 articles were excluded due to being a review, questionnaire, report or a cross-sectional study, which led to a total of 89 research articles. By excluding articles considering the influence of cold thermal environment on physical performance, additional 78 articles were excluded, which led to 11 articles on the influence of cold thermal environment on human cognitive fatigue and performance. These articles were assessed in a full-text version and screened thoroughly.

Full-text articles were excluded if they were not related to cognitive working performance in moderate cold thermal environment; if abstracts didn't have crucial parts as background, objective, methodology, results, discussion and conclusion; if objectives were not well defined; if the experimental methodology was not enough specified; if conclusions were made without any connection to experiment outcomes.

Finally, 8 articles were included in this short review, shown in the Figure 1. Included articles were published between 2000 and 2012, as only those articles passed the selection criteria.

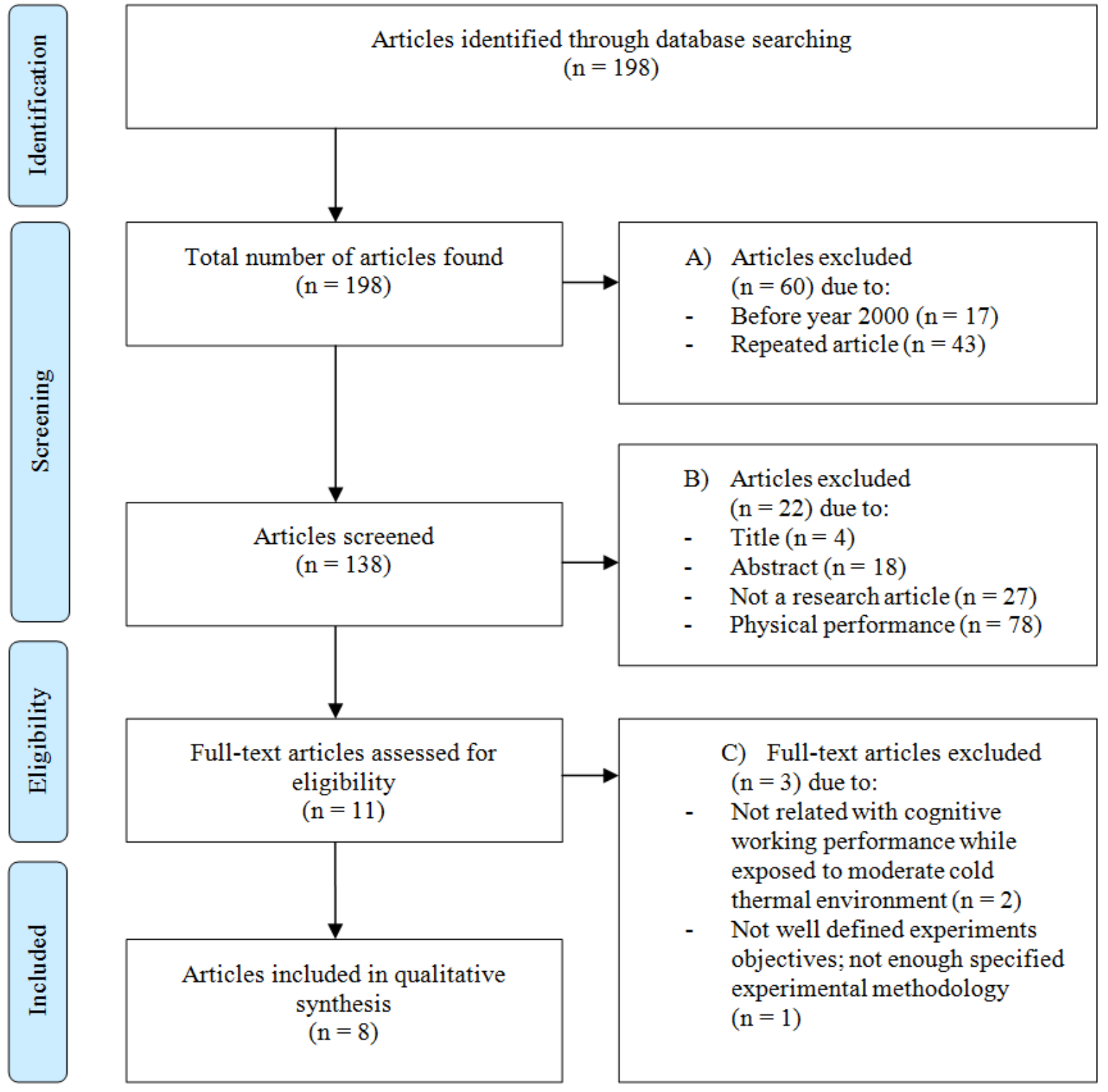

Figure 1: Selection of studies: summary of studies in order of level of evidence, with extracted data

Main results of this systematic review are shown in the Table 1 and Table 2. 


\begin{tabular}{|c|c|c|c|c|c|}
\hline Reference/Year & Subjects/Gender & $\begin{array}{l}\text { Mean Age } \\
\text { (years) }\end{array}$ & $\begin{array}{l}\text { Mean Height } \\
(\mathrm{cm})\end{array}$ & $\begin{array}{c}\text { Mean Weight } \\
(\mathrm{kg})\end{array}$ & $\begin{array}{c}\text { Mean Body fat } \\
\text { (\%) }\end{array}$ \\
\hline 1. (Muller et al. 2012) & 10 men & $23 \pm 1$ & $183 \pm 6$ & $85 \pm 5$ & $11 \pm 4$ \\
\hline $\begin{array}{l}\text { 2. (Spitznagel et al. } \\
\text { 2009) }\end{array}$ & 6 men & $\begin{array}{c}23.3 \pm 1.5 \\
\text { (range } 22-26)\end{array}$ & $\begin{array}{c}182.7 \pm 10.8 \\
\text { (range } 168.7- \\
198.0 \mathrm{~cm} \text { ) }\end{array}$ & $\begin{array}{c}85.2 \pm 6.7(75.2- \\
95.2)\end{array}$ & $\begin{array}{l}11.1 \pm 6.1 \text { (range } \\
5.4-18.3 \text { ) }\end{array}$ \\
\hline 3. (John Paul et al. 2010) & $\begin{array}{l}22 \text { men and } 1 \\
\text { women }\end{array}$ & $39.13 \pm 9.35$ & & & \\
\hline $\begin{array}{l}\text { 4. (Mäkinen, Palinkas, et } \\
\text { al. 2006) }\end{array}$ & 10 men & $22.5 \pm 1.6$ & $180.8 \pm 7.2$ & $72.4 \pm 7.3$ & $17.1 \pm 1.9$ \\
\hline 5. (Adam et al. 2008) & $\begin{array}{c}6 \text { men and } 2 \\
\text { women soldier }\end{array}$ & $24 \pm 6 y r$ & $170 \pm 6$ & $72.9 \pm 11.1$ & $22 \pm 6$ \\
\hline $\begin{array}{l}\text { 6. (Cheung, Westwood, } \\
\text { and Knox 2007) }\end{array}$ & $\begin{array}{l}14 \text { men and } 6 \\
\text { women }\end{array}$ & $\begin{array}{c}22.9 \pm 4.5 \text { (men) } \\
\text { and } 24.2 \pm 6.0 \\
\text { (women) }\end{array}$ & & $\begin{array}{c}74.9 \pm 7.1 \text { (men) } \\
\text { and } 63.1 \pm 8.2 \\
\text { (women) }\end{array}$ & $\begin{array}{c}11.4 \pm 4.4 \text { (men) } \\
\text { and } 19.5 \pm 2.8 \\
\text { (women) }\end{array}$ \\
\hline 7. (Muller et al. 2011) & 11 men & $21 \pm 1$ & & & $17 \pm 6$ \\
\hline $\begin{array}{l}\text { 8. (Hartley and MCcabe } \\
\text { 2001) }\end{array}$ & $\begin{array}{l}10 \text { men and } 10 \\
\text { women }\end{array}$ & $21.75 \pm 2$ & $173.55 \pm 8.32$ & $71.24 \pm 10.97$ & $17.93 \pm 4,50$ \\
\hline
\end{tabular}

Table 1: Selected articles: the summary in order of level of evidence, with main data and characteristics 

$\begin{array}{lc}10^{\circ} \mathrm{C} \text { and } 25^{\circ} \mathrm{C} & 3 \times\left(120 \mathrm{~min} \text { to } 10^{\circ} \mathrm{C} \text { and }\right. \\ \text { (air) } & \left.120 \mathrm{~min} \text { to } 25^{\circ} \mathrm{C}\right)\end{array}$

2. $10 \pm 0.5^{\circ} \mathrm{C}$ and $25^{\circ} \mathrm{C}$ (air)

$$
120 \mathrm{~min} \text { to } 25^{\circ} \mathrm{C} \text { ) }
$$

sitting

sitting and completing cognitive tasks on the pc

3. average $-5^{\circ} \mathrm{C} 14$ months (examinations sitting and performing (summer)

$$
\text { at the } 2^{\text {nd }} \text { month, } 7^{\text {th }}
$$$$
\text { cognitive tests }
$$

average $-24^{\circ} \mathrm{C}$ month and $12^{\text {th }}$ month)

(winter)

room $18-22^{\circ} \mathrm{C}$

(air)

4.
$10 \pm 0.3^{\circ} \mathrm{C}$ and
$1 \times\left(90 \mathrm{~min}\right.$ to $25^{\circ} \mathrm{C}$ and
sitting and performing

$25 \pm 0.3^{\circ} \mathrm{C}$ (air)

$120 \mathrm{~min}$ to $10^{\circ} \mathrm{C}$ )

$$
\text { cognitive tests }
$$

5.

$2^{\circ} \mathrm{C}, 20$ and $\quad 1 \times\left(60 \mathrm{~min}\right.$ to $20^{\circ} \mathrm{C}, 60$ $45^{\circ} \mathrm{C}$ (air) $\quad \min$ to $45^{\circ} \mathrm{C}$ and $50 \mathrm{~min}$

$$
\text { to } 2^{\circ} \mathrm{C} \text { ) }
$$

6

$\begin{array}{ccc}18-25^{\circ} \mathrm{C} & 60-90 \text { min (until rectal } \\ \text { (water) } & \begin{array}{c}\text { sitting while head-out } \\ \text { temperature drop } \\ 1.08^{\circ} \mathrm{C} \text { ) }\end{array} & \begin{array}{c}\text { immersion in cool water } \\ \text { and performed the } \\ \text { attention test }\end{array}\end{array}$

7.

$5 \pm 1^{\circ} \mathrm{C}$ and 25 $27^{\circ} \mathrm{C}$ (air)

$$
\begin{gathered}
\text { min to } 5 \pm 1^{\circ} \mathrm{C} \text { and } 60 \mathrm{~min} \\
\text { to } 25-27^{\circ} \mathrm{C}
\end{gathered}
$$

8. $\quad 0 \pm 2^{\circ} \mathrm{C}$ and

$18 \pm 2^{\circ} \mathrm{C}$ (air) integneurotm, digit span, choice reaction time, executive maze task

skin and rectal temperature, thermal sensation, oxygen consumption

choice reaction time, stroop test "color-word", the

$$
\text { mazes task }
$$

task acquisition, recognition memory, delayed recognition, attention and concentration, short-term

memory, digit symbol substitution, learning and memory from evaluating the accuracy of response

\section{automated neuropsychological assessment metric for isolated and confined environments}

sentry duty performance (simulation weaponeer), nasa-tlx and poms questionnaire

vigilance test, spatial attention test

$$
\text { attention test }
$$

watching the tv

\author{
stroop word-colour test, working memory test, signal \\ detection task, fitts' task
}

skin and rectal temperature, finger skin temp, thermal sensation, oxygen consumption, systolic and diastolic blood pressure, heart rate

skin and rectal temperature, oxygen consumption, the cold strain index was calculated

skin and rectal temperature, finger dexterity, heart rate

\section{skin and rectal temperature}

core temp, mvc/force output

Table 2: Selected articles: the summary in order of level of evidence, with main data and characteristics 


\section{Discussion}

Exposure to moderate cold thermal environment was found to decrease the reaction time and executive function (Muller et al. 2012; Spitznagel et al. 2009; Mäkinen, Palinkas, et al. 2006; Adam et al. 2008), and decreasing in attention (Spitznagel et al. 2009; Mäkinen, Palinkas, et al. 2006; Adam et al. 2008; Cheung, Westwood, and Knox 2007; Muller et al. 2011; Hartley and MCcabe 2001). The cognitive working performances experimented by included articles are shown in the Table 3:

\begin{tabular}{|c|c|c|c|c|c|c|c|c|}
\hline Reference & $\begin{array}{l}\text { Working } \\
\text { Memory }\end{array}$ & $\begin{array}{l}\text { Long-term } \\
\text { Memory }\end{array}$ & $\begin{array}{l}\text { Short- } \\
\text { term } \\
\text { Memory }\end{array}$ & $\begin{array}{l}\text { Reaction } \\
\text { time }\end{array}$ & $\begin{array}{l}\text { Executive } \\
\text { function }\end{array}$ & Attention & Accuracy & Mood \\
\hline 1. & Decreased & & & Decreased & Decreased & & & \\
\hline 2. & & & & Decreased & Decreased & Decreased & & \\
\hline 3. & & Increased & Same & & & & & \\
\hline 4. & & & Same & Decreased & Same & Decreased & Increased & \\
\hline 5. & & & & Decreased & Decreased & Decreased & & Decreased \\
\hline 6. & & & & & & Decreased & & \\
\hline 7. & & & & & & Same & & Decreased \\
\hline 8. & Decreased & & & & & Decreased & & \\
\hline
\end{tabular}

Table 3: The cognitive working performances experimented by included articles

One study found that cognitive dysfunctions persist for some time after the cold exposure and despite the stabilization of the core and skin temperature and thermal sensation (Muller et al. 2012). The additive effect of sleep deprivation to cold exposure was found in basic attention, reaction time and functioning, where it was generally worsened in the presence of both, relative to cold exposure alone (Spitznagel et al. 2009).

Major dispute among the included articles were on the influence of cold thermal environment on memory. While two articles found working memory to generally decrease (Muller et al. 2012; Hartley and MCcabe 2001), some articles found short-term memory to stay the same even after exposure (John Paul et al. 2010; Mäkinen, Palinkas, et al. 2006) and one of them found long-term memory to increase (John Paul et al. 2010).

Some of the less investigated cognitive parameters were accuracy, which was found to be higher in cold environment by one author (Mäkinen, Palinkas, et al. 2006) and mood, which was found to be decreased when exposed to cold thermal environment (Adam et al. 2008; Muller et al. 2011). Additional experiments should be conducted in order to get consistent results on the influence of cold environment on accuracy and mood.

Most articles excluded female subjects in order to eliminate potential confounds of hormonal fluctuation on thermoregulation, some are presented in this systematic review. However, there are many industries with moderate and severe cold thermal environment, where a high percentage of female workers could be usually found (e.g. the food industry). As it was concluded by some previous research (Janse de Jonge 2003), high differences were found in females between the follicular and the luteal phase of the menstrual cycle. Therefore experiments of the influence of cold on cognitive performance of females need a further research in order to get additional information on monthly changes and possibly adapt the working schedule of female workers according to their menstrual cycle phases. By doing that a higher production and a lower level of health and safety risks might be achieved. There are several articles conducting experiments on both genders (Hartley and MCcabe 2001; Cheung, Westwood, and Knox 2007; Adam et al. 2008; Man and Omel 2008; 
John Paul et al. 2010), but it is also noticeable that for most of them the number of female subjects is much lower than the number of male subjects (John Paul et al. 2010; Adam et al. 2008; Cheung, Westwood, and Knox 2007).

More laboratory and industrial experiments should be conducted in order to further the knowledge on the influence of cold thermal environment on cognitive performance. Experiments should be conducted in different cold thermal environment temperatures, with different relative humidity and air movement speed. Different tasks should be considered using physically healthy subjects of both genders but differently aged groups. Experiments should be conducted on non-habituated and habituated subjects in order to make consistent conclusions on cognitive performances while exposed to cold thermal environment.

\section{Limitations}

This study has several limitations. Most of the chosen articles did not considered several bias factors which might had influenced the subject physical and therefore immediately cognitive results: number of sleeping hours; smoking cigarettes; consumption of alcohol, tea or coffee at least 12 hours prior to the test; how much and which kind of food the subject ate; the phase of the menstrual cycle; illness history; medical control; medicine taking or physical exertion at least 12 hours prior to the test. Controlling those biases might have improved results and therefore conclusions from the experiments. One of the limitations was using only the institutional IP address of the University of Porto, therefore the search was limited to databases on which the university was subscribed to. Limiting the review to articles published after the year $\mathbf{2 0 0 0}$ might have excluded some articles which might benefit to this systematic review.

\section{Conclusions}

The findings of this systematic review indicate that moderate cold thermal environment decrease cognitive working performance, particularly reaction time, executive function and attention, while there is still a dispute on the influence of cold on the working memory, depending on short-term or long-term exposure. It was found that cognitive performance remained affected for some time after cold exposure, even after the core and skin body temperature were stabilized. The influence on mood and accuracy was found not to be very investigated. There is a certain number of limitations for this systematic review, as included articles in most cases didn't considered bias factors which were mentioned in the section limitations. Further experiments should be conducted on the cognitive working performance in moderate cold thermal environment, considering different air temperatures, including both genders and differently aged subjects in order to get results of greater quality and consistency.

\section{References}

Adam, Gina E, Robert Carter, Samuel N Cheuvront, Donna J Merullo, John W Castellani, Harris R Lieberman, and Michael N Sawka. 2008. "Hydration Effects on Cognitive Performance during Military Tasks in Temperate and Cold Environments." Physiology \& Behavior 93 (4-5) (March 18): 748-56. DOI: 10.1016/j.physbeh.2007.11.028.

Cheung, Stephen S, David a Westwood, and Matthew K Knox. 2007. "Mild Body Cooling Impairs Attention via Distraction from Skin Cooling." Ergonomics 50 (2) (February): 27588. DOI: 10.1080/00140130601068683.

Hartley, K., and J. MCcabe. 2001. The Effects of Cold on Human Cognitive Performance Implications for Design, School of Health and Human Performance, Dalhousie University, 
Halifax NS, Canada. Proceedings of the SELF-ACE 2001 Conference - Ergonomics for Changing Work, 297-305.

Janse de Jonge, Xanne a K. 2003. "Effects of the Menstrual Cycle on Exercise Performance." Sports Medicine (Auckland, N.Z.) 33 (11) (January): 833-51.

John Paul, F.U., Manas K. Mandal, K. Ramachandran, and M.R. Panwar. 2010. "Cognitive Performance during Long-Term Residence in a Polar Environment." Journal of Environmental Psychology 30 (1) (March): 129-132. DOI: 10.1016/j.jenvp.2009.09.007.

Liberati, Alessandro, Douglas G Altman, Jennifer Tetzlaff, Cynthia Mulrow, John P A Ioannidis, Mike Clarke, P J Devereaux, Jos Kleijnen, and David Moher. 2009. "Academia and Clinic The PRISMA Statement for Reporting Systematic Reviews and Meta-Analyses of Studies That Evaluate Health Care Interventions :" Annals of Internal Medicine 151 (4).

Mäkinen, Tiina M. 2007. "Human Cold Exposure, Adaptation, and Performance in High Latitude Environments." American Journal of Human Biology 164 (December 2006): 155164. DOI: 10.1002/ajhb.

Mäkinen, Tiina M, Lawrence a Palinkas, Dennis L Reeves, Tiina Pääkkönen, Hannu Rintamäki, Juhani Leppäluoto, and Juhani Hassi. 2006. "Effect of Repeated Exposures to Cold on Cognitive Performance in Humans." Physiology \& Behavior 87 (1) (January 30): 166-76. DOI: 10.1016/j.physbeh.2005.09.015.

Mäkinen, Tiina M, Veli-Pekka Raatikka, Mika Rytkönen, Jari Jokelainen, Hannu Rintamäki, Reija Ruuhela, Simo Näyhä, and Juhani Hassi. 2006. "Factors Affecting Outdoor Exposure in Winter: Population-Based Study." International Journal of Biometeorology 51 (1) (September): 27-36. DOI: 10.1007/s00484-006-0040-0.

Man, P, and T G Omel. 2008. "Effect of Cold Stimulation of the Arm Fingers on the Spectral / Coherent EEG Characteristics in Humans." Neurophysiology 40 (3): 228-230.

Muller, Matthew D, John Gunstad, Michael L Alosco, Lindsay a Miller, John Updegraff, Mary Beth Spitznagel, and Ellen L Glickman. 2012. "Acute Cold Exposure and Cognitive Function: Evidence for Sustained Impairment." Ergonomics 55 (7) (January): 792-8. DOI: 10.1080/00140139.2012.665497.

Muller, Matthew D, Sarah M Muller, Chul-Ho Kim, Edward J Ryan, John Gunstad, and Ellen L Glickman. 2011. "Mood and Selective Attention in the Cold: The Effect of Interval versus Continuous Exercise." European Journal of Applied Physiology 111 (7) (July): 1321-8. DOI: 10.1007/s00421-010-1759-1.

Spitznagel, Mary Beth, John Updegraff, Katie Pierce, Kristen H. Walter, Tiffany Collinsworth, Ellen Glickman, and John Gunstad. 2009. "Cognitive Function During Acute Cold Exposure With or Without Sleep Deprivation Lasting 53 Hours." Aviation, Space, and Environmental Medicine 80 (8) (August 1): 703-708. DOI: 10.3357/ASEM.2507.2009.

Tochihara, Yutaka. 2005. "Work in Artificial Cold Environments." Journal of Physiological Anthropology and Applied Human Science 24 (1) (January): 73-6. 